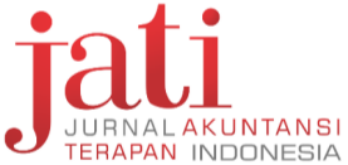

Jati: Jurnal Akuntansi Terapan Indonesia Vol 1 No 1 Hal 27-37 Maret 2018

\title{
Analisis Kinerja Anggaran Belanja Pada Dinas Kebudayaan Daerah Istimewa Yogyakarta Tahun 2012- 2016
}

http://journal.umy.ac.id/index.php/jati

(C)2018 JATI. All rights reserved

DOI: 10.18196/jati.010103

\section{DATA ARTIKEL:}

Diterima: 31 Jan 2018

Direviu: 18 Feb 2018

Direvisi: 10 Mar 2018

Disetujui: 12 Mar 2018

TOPIK ARTIKEL:

Akuntansi Sektor Publik

\author{
SAKINA NUSARIFA TANTRI* DAN PUTRI IRMAWATI \\ Universitas Gadjah Mada \\ *Email korespondensi: sakina.tantri@ugm.ac.id
}

\begin{abstract}
ABSTRAK: Penelitian ini bertujuan untuk menganalisis kinerja anggaran belanja Dinas Kebudayaan Daerah istimewa Yogyakarta tahun 2012 - 2016. Analisis yang digunakan meliputi: analisis varians belanja, analisis partumbuhan belanja, analisis keserasian belanja, rasio efisiensi belanja dan rasio efektivitas. Analisis ini tepat digunakan karena dapat mengukur penggunaan anggaran belanja secara ekonomis, efektif, dan efisien. Metode yang digunakan adalah metode kualitatif yang diolah menggunakan analisis deskriptif. Data yang digunakan adalah laporan realisasi anggaran yang diperoleh langsung dari Dinas Kebudayaan Daerah istimewa Yogyakarta. Berdasarkan hasil penelitian dapat diketahui bahwa: (1) hasil analisis varians belanja dan analisis pertumbuhan belanja di Dinas Kebudayaan Daerah istimewa Yogyakarta sudah berjalan dengan baik; (2) analisis keserasian belanja

ABSTRACT: This research aims to analyze the performance of the budget of Dinas Kebudayaan Daerah istimewa Yogyakarta for the period of 2012 - 2016. The analysis used includes: expenditure variance analysis, expenditure growth analysis, expenditure harmony analysis, efficiency ratio and effectiveness ratio. The method used in this research is qualitative method and the data are analyzed using descriptive analysis. The data used is the budget realization report for the period of 2012 - 2016 obtained directly from Dinas Kebudayaan Daerah istimewa Yogyakarta. The results of this research are: (1) the expenditure variance analysis and expenditure growth analysis in Dinas Kebudayaan Daerah istimewa Yogyakarta shows a good performance; (2) the result of the expenditure harmony analyisis indicates that the relevant offices have done such harmonization of regional expenditure; (3) from the efficiency ratio, it can be seen that Dinas Kebudayaan Daerah istimewa Yogyakarta has been doing efficiency by using the budget not exceed its realization. However, there is one program that is not running effectively and efficiently. Meanwhile, relevant agencies are considered to be effective in using the indirect budget. Overall, the budget performance of Dinas Kebudayaan Daerah istimewa Yogyakarta 2012-2016 is considered good.
\end{abstract} menunjukkan bahwa dinas sudah melakukan harmonisasi belanja daerah; (3) Dinas Kebudayaan Daerah istimewa Yogyakarta sudah melakukan efisiensi dengan menggunakan anggaran tidak melebihi realisasinya. Namun, terdapat salah satu program yang tidak berjalan secara efisien dan untuk hasil perhitungan dari rasio efektivitas dinas terkait dinilai sudah efektif dalam menggunakan anggaran belanja tidak langsung. Secara keseluruhan, kinerja anggaran belanja Dinas Kebudayaan Daerah istimewa Yogyakarta tahun 2012-2016 baik.

Kata Kunci: Anggaran; Belanja; Kinerja; Efektivitas; Efisiensi
Keywords: Budget; Expenditure; Performance; Effectiveness; Efficiency

\section{SITASI ARTIKEL:}

Tantri, S. N., \& Irmawati, P. (2018). Analisis Kinerja Anggaran Belanja Pada Dinas Kebudayaan Daerah Istimewa Yogyakarta Tahun 2012-2016. Jati: Jurnal Akuntansi Terapan Indonesia, 1(1), 27-37.

\section{PENDAHULUAN}

Daerah Istimewa Yogyakarta (DIY) terkenal dengan beragam potensi budayanya, baik budaya fisik maupun non fisik. Cagar budaya, sistem nilai, perilaku sosial dan norma 
karya seni menjadi ciri khas DIY. Seiring perkembangan pengetahuan dan teknologi, tidak menutup kemungkinan bahwa budaya yang melekat ini lambat laun akan pudar. Yunus (2013) mengungkapkan bahwa nilai-nilai budaya telah mengalami transformasi dan hal ini dapat berpengaruh terhadap karakter bangsa. Sebagai provinsi yang memiliki daya tarik wisata yang besar di Indonesia, salah satunya dikarenakan ragam budayanya, maka diperlukan perhatian khusus dari pemerintah provinsi setempat dalam mengembangkan potensi budaya tersebut, agar nilai budaya yang melekat di provinsi ini tidak tergerus perkembangan zaman. Salah satu upaya untuk memperhatikan potensi budaya ini adalah dengan mengoptimalkan penggunaan sumber daya di Dinas Kebudayaan DIY. Dinas Kebudayaan DIY sebagai lembaga yang berperan penting dalam pengelolaan budaya di DIY sepatutnya melakukan pengelolaan dana secara efektif dan efisien agar sektor budaya di DIY dapat terus mengalami perkembangan.

Era otonomi daerah mulai diberlakukan di Indonesia berdasarkan Undang-undang Nomor 22 Tahun 1999 tentang Pemerintahan Daerah. Undang-undang ini kemudian digantikan dengan Undang-undang Nomor 32 Tahun 2004. Kebijakan otonomi daerah pada dasarnya diarahkan untuk mendorong peningkatan kapasitas pemerintah daerah dalam memberikan pelayanan kepada masyarakat. Dalam melaksanakan kegiatan berupa pelayanan kepada masyarakat, suatu daerah tidak dapat menjalankannya tanpa adanya anggaran. Hal ini dikarenakan anggaran merupakan dasar agar pemerintah mampu beroperasi. Anggaran adalah dokumen yang berisi estimasi kinerja, berupa penerimaan dan pengeluaran, yang disajikan dalam ukuran moneter yang akan dicapai pada periode waktu tertentu dan menyertakan data masa lalu sebagai bentuk pengendalian dan penilaian kerja. Tujuan adanya anggaran sektor publik yaitu untuk meningkatkan pelayanan publik dan kesejahteraan masyarakat (Halim dan Kusufi, 2014). Beberapa alasan mengapa anggaran sektor publik menjadi penting antara lain: (1) sebagai alat pemerintah untuk mengarahkan pembangunan, menjamin kesinambungan, dan meningkatkan kualitas hidup masyarakat, (2) adanya kebutuhan dan keinginan masyarakat yang tidak terbatas dan terus berkembang, sedangkan sumber daya yang ada terbatas, dan (3) meyakinkan bahwa pemerintah telah bertanggungjawab terhadap rakyat dalam hal anggaran yang berperan sebagai instrumen akuntabilitas publik. Setiap lembaga pemerintahan wajib membuat anggaran agar penggunaan dana menjadi efisien dan efektif. Untuk menunjang hal tersebut, pemerintah menerapkan prinsip good governance khususnya dalam pengelolaan keuangan daerah karena keuangan daerah berdampak secara langsung pada perubahan struktur Anggaran Pendapatan dan Belanja Daerah (APBD).

Gubernur DIY menyoroti beberapa program yang dilaksanakan oleh Dinas Kebudayaan DIY yang menyerap anggaran cukup besar, salah satunya adalah anggaran belanja perjalanan dinas yang digunakan untuk pengenalan budaya ke luar negeri. Berdasarkan data yang diperoleh dari Dinas Kebudayaan DIY tahun 2013, anggaran perjalanan dinas sebesar Rp 250.000.000 dengan realisasi sebesar Rp 237.269.500. Selain itu, terjadi peningkatan yang cukup besar di tahun 2014 yang realisasinya mencapai Rp 9.315.664.155 dari total anggaran Rp 12.345.511.810. Hal ini membuat Kementerian Dalam Negeri (Kemendagri) mendesak pembatalan anggaran perjalanan ke luar negeri bagi kegiatan monitoring dan evaluasi Badan Kerjasama dan Penanaman Modal untuk kegiatan diplomasi budaya di Dinas Kebudayaan. Tidak hanya belanja perjalanan dinas yang disoroti, tetapi juga honorarium Pegawai Negeri Sipil (PNS) maupun non PNS. Gubernur Daerah istimewa Yogyakarta Sri Sultan Hamengku Buwono $\mathrm{X}$ meminta agar dilakukan pengurangan APBD Kota Yogya tahun 2017 pada pos-pos tersebut (www.harianjogja.com, 2016).

Saat ini masyarakat telah berada pada era keterbukaan. Teknologi informasi dan komunikasi sudah demikian maju dan berkembang dari waktu ke waktu. Masyarakat semakin mudah untuk mendapatkan berbagai informasi dengan biaya yang relatif murah. Dalam hal pengelolaan uang publik pun, masyarakat semakin cerdas untuk menuntut transparansi. Salah satu cara untuk menilai kinerja pemerintah adalah dengan mengetahui kinerja pemerintah yang diukur menggunakan indikator tertentu. Menurut Mahsun (2016), pengukuran kinerja merupakan suatu sistem yang bertujuan untuk membantu manajer publik menilai pencapaian suatu strategi melalui alat ukur finansial dan nonfinansial. Sementara itu, menurut Darise (2007), indikator kinerja adalah ukuran kuantitatif dan atau kualitatif yang menggambarkan tingkat pencapaian suatu sasaran atau tujuan yang telah ditetapkan. Adapun persyaratan penyusunan indikator dan sasaran kinerja menurut Darise (2007) adalah: (1) spesifik dan jelas, sehingga tidak ada kemungkinan kesalahan interpretasi, (2) dapat diukur secara objektif, (3) harus menangani aspek aspek objektif yang relevan, (4) harus berguna untuk menunjukkan keberhasilan operasional, keluaran, hasil, manfaat, dan dampak, (5) sensitif terhadap perubahan (6) terukur baik secara kuantitatif maupun kualitatif, dan (7) dapat dikumpulkan, diolah, dan dianalisis datanya dengan biaya 
yang tersedia. Dalam konteks kinerja pemerintahan di Indonesia, penyajian laporan keuangan merupakan salah satu bentuk pertanggungjawaban tertulis atas kinerja keuangan yang telah dicapai, sehingga dapat dijadikan dasar untuk mengukur kinerja pemerintah. Salah satu komponen laporan keuangan yang dipublikasikan adalah laporan realisasi anggaran (LRA).

Laporan Realisasi Anggaran (LRA) merupakan komponen laporan keuangan pemerintah yang menyajikan informasi tentang realisasi dan anggaran entitas pelaporan secara tersanding untuk suatu periode tertentu (Ratmono \& Solihin, 2015). LRA menjadi salah satu laporan pertanggungjawaban keuangan daerah yang utama. LRA disajikan sekurang-kurangnya sekali dalam setahun. Penyajian LRA harus disajikan tepat waktu, yaitu selambat-lambatnya enam bulan setelah berakhirnya tahun anggaran. Tujuan adanya LRA (PP No.71 Tahun 2010) antara lain: (1) menetapkan dasardasar penyajian laporan realisasi anggaran untuk pemerintah dalam rangka memenuhi tujuan akuntabilitas sebagaimana ditetapkan oleh peraturan perundang-undangan, (2) memberikan informasi realisasi dan anggaran entitas pelaporan. Perbandingan antara anggaran dan realisasinya menunjukkan tingkat ketercapaian target-target yang telah disepakati antara legislatif dan eksekutif sesuai dengan peraturan perundang-undangan.

Berdasarkan definisi ukuran dan indikator kinerja seperti diuraikan di atas, LRA sebagai alat ukur finansial dinilai mampu menggambarkan pencapaian kinerja pemerintah daerah. Salah satu komponen yang merupakan indikator penting dalam penilaian kinerja berdasarkan LRA adalah komponen belanja daerah. Belanja daerah didefinisikan sebagai semua pengeluaran dari rekening kas umum daerah yang mengurangi ekuitas dana lancar dalam periode tahun anggaran bersangkutan yang tidak akan diperoleh pembayarannya kembali oleh pemerintah daerah (Mahmudi, 2007). Sedangkan menurut Bastian (2006), belanja daerah merupakan perkiraan beban pengeluaran daerah yang dialokasikan secara adil dan merata agar relatif dapat dinikmati oleh seluruh kelompok masyarakat tanpa diskriminasi, khususnya dalam pemberian pelayanan umum. Ratmono dan Solihin (2015) menyatakan bahwa belanja daerah dipergunakan dalam rangka menandai pelaksanaan urusan pemerintahan yang menjadi kewenangan provinsi atau kabupaten/kota yang terdiri atas: (1) belanja operasi, yaitu pengeluaran anggaran untuk kegiatan sehari hari pemerintah pusat/daerah yang memberi manfaat jangka pendek. Belanja operasi terdiri atas belanja operasi (di antaranya belanja pegawai, belanja barang, belanja bunga, belanja subsidi, hibah, dan bantuan sosial); (2) hibah, yaitu pengeluaran pemerintah dalam bentuk uang/ barang atau jasa kepada pemda lainnya, perusahaan daerah, masyarakat, dan organisasi kemasyarakatan; dan (3) bantuan sosial, yaitu transfer uang atau barang yang diberikan kepada masyarakat guna melindungi dari kemungkinan terjadinya risiko sosial.

Pelaksanaan otonomi daerah dan desentralisasi fiskal diharapkan dapat meningkatkan pemerataan pembangunan daerah, sesuai dengan motivasi daerah untuk mengembangkan wilayahnya berdasarkan potensi unggulan daerah (Sasana, 2011). Karena DIY adalah provinsi yang memiliki budaya sebagai potensi unggulannya, terlebih lagi DIY merupakan salah satu pusat kebudayaan, khususnya kebudayaan Jawa (Adrisijanti, 2007), maka perlu dilakukan analisis terkait penggunaan sumber daya yang optimal untuk dapat meningkatkan pembangunan daerah tersebut. Optimalisasi sumber daya terkait kebudayaan dapat diketahui melalui analisis penggunaan anggaran belanja yang dilakukan di Dinas Kebudayaan DIY. Analisis tersebut didasarkan pada Laporan Realisasi Anggaran tahun 2012 - 2016. Penelitian ini diharapkan dapat memberikan kontribusi berupa wawasan dalam hal pengukuran kinerja anggaran belanja pemerintah daerah. Selain itu, penelitian ini juga ditujukan untuk menambah referensi dalam pengembangan penelitian selanjutnya.

\section{METODE PENELITIAN}

Penelitian ini adalah penelitian kualitatif yang dilakukan untuk menganalisis kinerja anggaran belanja pada suatu daerah tertentu, yaitu Daerah Istimewa Yogyakarta. Penelitian ini dilakukan mulai bulan Maret sampai dengan Juni 2017. Pengumpulan data pada penelitian ini dilakukan dengan dua macam teknik antara lain dokumentasi dan studi pustaka. Dokumentasi dilakukan untuk memperoleh data-data yang diperlukan, yaitu dokumen LRA DIY tahun 2012 - 2016, sedangkan studi pustaka dilakukan untuk memperoleh referensi dari buku, peraturan undang-undang, dan jurnal ilmiah yang relevan. Aalur penulisan penelitian yang dilakukan penulis disajikan pada Gambar 1.

Data yang diperoleh melalui proses dokumentasi adalah data berupa angka yang kemudian diolah menggunakan metode analisis deskriptif. Data berupa angka yang dimaksud adalah hasil perhitungan kinerja belanja anggaran, antara lain varians belanja, pertumbuhan belanja, keserasian belanja, rasio efisiensi belanja, dan rasio efektivitas belanja. Berdasarkan rangkuman dari beberapa 


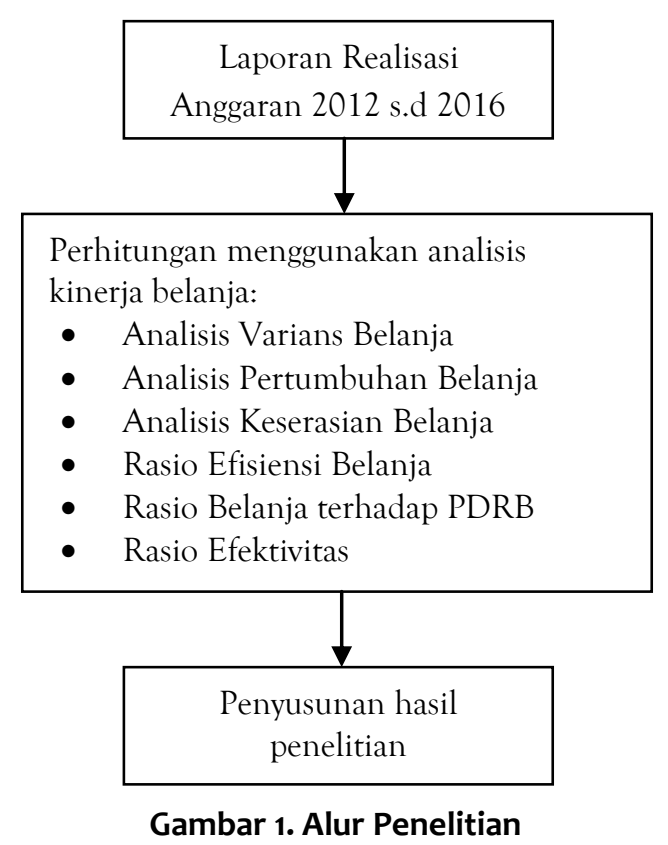

literatur yaitu Mahmudi (2007), Liando dan Elim (2016), Pangkey dan Pinatik (2015), Kainde (2013), serta Fahrianta dan Carolina (2012), perhitunganperhitungan rasio analisis belanja anggaran dapat dilakukan sebagai berikut:

\section{Varians Belanja}

Data yang digunakan untuk melakukan analisis varians belanja adalah realisasi belanja dan anggaran belanja Dinas Kebudayaan DIY tahun 2012 $-2016$.

Varians belanja $=$ Realisasi Belanja -Anggaran Belanja

Kategori varians belanja dibedakan menjadi dua, yaitu: (1) Selisih disukai (favourable variance): realisasi belanja < anggaran belanja; dan (2) Selisih tidak disukai (unfavourable variance): realisasi belanja > anggaran belanja

\section{Pertumbuhan Belanja}

Pertumbuhan belanja yang dianalisis adalah pertumbuhan belanja daerah, pertumbuhan belanja langsung, dan pertumbuhan belanja tidak langsung tahun $2012-2016$.

Pertumbuhan Belanja $=$

$$
\frac{\text { Realisasi Belanja Thrnt }+ \text { Realisasi Belanja Thn to-1 }}{\text { Realisasi Belanja Thn }}
$$

\section{Keserasian Belanja}

Keserasian belanja meliputi tiga aspek, yakni:
(1) Belanja operasi terhadap total belanja. Data yang digunakan dalam analisis ini adalah data belanja operasi tahun 2012 2016.

Belanja operasi terhadap total belanja =

$$
\text { Realisasi Belanja Operasi }
$$

(2) Belanja modal terhadap total belanja. Analisis ini menggunakan data belanja modal Dinas Kebudayaan DIY tahun 2012 - 2016.

Belanja modal terhadap total belanja= Realisasi Belanja Mlodal]

(3) Belanja langsung dan tidak langsung terhadap total belanja. Analisis ini menggunakan data belanja langsung dan belanja tidak langsung yang dilakukan oleh Dinas Kebuda-yaan DIY tahun 2012 - 2016.

Belanja langsung terhadap total belanja = Total Belanja Langusung

Belanja tidak langsung terhadap total belanja $=\frac{\text { Total Belanja TdkLangsung }}{\text { Total Belania Daerah }}$

\section{Rasio Efisiensi Belanja}

Untuk melakukan analisis ini, diperlukan data anggaran dan realisasi belanja tahun 2012 - 2016 .

\section{Rasio Efisiensi Belanja $=\frac{\text { Realisasi Belanja }}{\text { Anggaran Belanja }} \times 100 \%$}

Pemerintah daerah dinilai telah melakukan efisiensi anggaran jika rasio efisiensinya kurang dari $100 \%$.

\section{Rasio Efektivitas Belanja}

Untuk melakukan analisis ini, diperlukan data anggaran belanja tidak langsung tahun 2012 - 2016 . Berikut ini adalah standar efektivitas menurut Keputusan Menteri Dalam Negeri No. 690.900-327 tahun 1996 tentang kriteria penilaian dan kinerja keuangan dapat diketahui efektif atau tidak dengan memenuhi kriteria sebagai berikut:

- Tingkat pencapaian diatas $100 \%$ berarti sangat efektif.

- Tingkat pencapaian antara $90 \%-100 \%$ berarti efektif.

- Tingkat pencapaian antara 80\%-90\% berarti cukup efektif.

- Tingkat pencapaian antara 60\%-80\% berarti kurang efektif.

- Tingkat pencapaian dibawah $60 \%$ berarti tidak efektif. 


$$
\text { Rasio Efektivitas Belanja }=\frac{\text { Realisasi Belanja }}{\text { Target Belanja }} \times 100 \%
$$

\section{HASIL DAN PEMBAHASAN}

Dari hasil analisis peneliti, maka diperoleh nilainilai dari perhitungan rasio kinerja anggaran belanja sebagai berikut:

\section{Analisis Varians Belanja}

Hasil dari analisis varians belanja menunjukkan bahwa Dinas Kebudayaan DIY telah melakukan penghematan anggaran dengan baik, seperti terlihat pada tabel 1. Pada tahun 2012 terdapat selisih antara realisasi dengan anggaran belanja sebesar Rp 2.847.068.125. Selisih yang dihasilkan menunjukkan angka negatif yang berarti terjadi penghematan anggaran sebesar 5,70\%. Sementara itu, pada tahun 2013, Dinas Kebudayaan DIY berhasil melakukan penghematan anggaran sebesar $67,62 \%$ dan hanya menyerap anggaran sebesar 32,38\%. Penyerapan anggaran tahun 2013 menunjukkan angka rendah. Hal ini dikarenakan ada capaian indikator organisasi budaya berkategori maju yang belum tercapai di tahun tersebut. Berdasarkan Laporan Keterangan Pertanggungjawaban (LKPJ) Yogyakarta tahun 2013 menyebutkan bahwa permasalahan utama adalah variasi kondisi organisasi budaya yang ada, sehingga tidak memungkinkan kegiatan pembinaan organisasi budaya hanya dilakukan dalam 1 tahun anggaran. Untuk meningkatkan status organisasi budaya yang kondisinya kurang baik, walaupun masuk dalam status berkembang membutuhkan waktu pem- binaan lebih dari satu tahun anggaran. Pada tahun 2014, penghematan yang dilakukan mulai menurun menjadi 41,07\%. Namun, penyerapan anggarannya lebih tinggi yaitu sebesar 58,93\%, sedangkan penghematan terus menurun hingga tahun 2016 yaitu sebesar 6,32\% atau Rp 10.735.076.343 dengan penyerapan anggaran sebesar 93,68\%. Penyerapan anggaran tahun 2016 meningkat pesat dikarenakan banyaknya program yang berjalan dengan baik atau terealisasikan di tahun ini seperti pencapaian rehabilitasi Taman Budaya Yogyakarta dan pembangunan Taman Budaya Kulonprogo dan tercapainya implementasi acara Orchestra Melbourne Syhmphony yang merupakan tindak lanjut dari kerjasama DIY dengan Australia. Anggaran belanja yang dianggarkan setiap tahun di Dinas Kebudayaan DIY selalu meningkat. Namun, Dinas Kebudayaan DIY dapat melakukan penghematan anggaran. Oleh karena itu, dapat dikatakan bahwa Dinas Kebudayaan DIY telah melakukan penghematan anggaran dengan baik.

\section{Analisis Pertumbuhan Belanja}

Hasil analisis pertumbuhan belanja daerah, pertumbuhan belanja langsung, dan pertumbuhan belanja tidak langsung tahun 2012 - 2016 ditunjukkan pada tabel 2. Berdasarkan tabel 2, terdapat pertumbuhan belanja tahun 2012 ke 2013 sebesar 15,30\%. Peningkatan pertumbuhan belanja daerah meningkat pesat tahun 2013 ke 2014 sebesar $343,43 \%$, hal ini dikarenakan adanya inflasi. Inflasi yang sangat tinggi pada tahun tersebut berdampak terhadap pertumbuhan belanja karena umumnya

Tabel 1. Analisis Varians Belanja

\begin{tabular}{ccccc}
\hline Tahun & Realisasi $(\mathrm{Rp})$ & Anggaran $(\mathrm{Rp})$ & Selisih $(\mathrm{Rp})$ & Persentase $(\%)$ \\
\hline 2012 & 47.080 .724 .756 & 49.927 .729 .881 & $(2.847 .068 .125)$ & $-5,70$ \\
2013 & 54.283 .630 .289 & 167.644 .664 .546 & $(113.361 .034 .257)$ & $-67,72$ \\
2014 & 240.708 .960 .958 & 408.481 .993 .909 & $(167.771 .032 .951)$ & $-41,07$ \\
2015 & 344.889 .146 .897 & 410.750 .387 .594 & $(65.861 .240 .697)$ & -16.03 \\
2016 & 159.081 .890 .933 & 169.816 .967 .276 & $(10.735 .076 .343)$ & $-6,32$ \\
Rata-rata & & & & $-27,35$ \\
\hline
\end{tabular}

Sumber : Dinas Kebudayaan DIY (Data Diolah)

Tabel 2. Analisis Pertumbuhan Belanja

\begin{tabular}{cccc}
\hline Tahun & Realisasi Anggaran Belanja $(\mathrm{Rp})$ & Pertumbuhan Belanja $(\mathrm{Rp})$ & Keterangan $(\%)$ \\
\hline 2012 & 47.080 .724 .756 & - & 0,00 \\
2013 & 54.283 .630 .289 & 7.202 .905 .533 & 15,30 \\
2014 & 240.708 .960 .958 & 186.425 .330 .669 & 343,43 \\
2015 & 344.889 .146 .897 & 104.180 .185 .939 & 43,28 \\
2016 & 159.081 .890 .933 & $(185.807 .255 .964)$ & $-53,87$ \\
\hline
\end{tabular}

Sumber : Dinas Kebudayaan DIY (Data Diolah) 
Tabel 3. Inflasi di Indonesia Tahun 2012-2016

\begin{tabular}{cc}
\hline Tahun & Inflasi (\%) \\
\hline 2012 & 4,30 \\
2013 & 8,38 \\
2014 & 8,36 \\
2015 & 3,35 \\
2016 & 3,02 \\
\hline
\end{tabular}

Sumber : www.bps.go.id (Data Diolah)

belanja dipengaruhi oleh penyesuaian inflasi, perubahan kurs rupiah, dan faktor makro lain. Tahun 2014 ke 2015 pertumbuhan belanja mengalami penurunan sebesar $43,28 \%$. Hal ini wajar terjadi karena inflasi juga mengalami penurunan yang signifikan. Sementara itu, dari tahun 2015 ke 2016, pertumbuhan belanja dinas mengalami penurunan yang sangat drastis, yaitu sebesar $-53,87 \%$. Hal ini terjadi karena realisasi anggaran yang lebih rendah dari tahun sebelumnya dan terjadi pengurangan penggunaan anggaran di pos belanja langsung, berupa belanja barang dan jasa. Dinas Kebudayaan DIY mengusulkan penghapusan 4 mobil dinas dengan tidak mengeluarkan biaya perpanjangan STNK, hal ini dilakukan karena mobil tersebut sudah tidak layak pakai, dan sudah digantikan dengan yang baru.

Untuk memberikan gambaran lebih spesifik, analisis pertumbuhan belanja dilakukan dengan analisis secara terpisah pada belanja langsung dan belanja tidak langsung. Hasilnya tampak pada tabel 4 dan 5. Pertumbuhan belanja langsung Dinas Kebudayaan DIY tahun 2012 ke 2013 mengalami kenaikan sebesar $18,44 \%$ dan meningkat pesat pada tahun 2014 sebesar 411,48\% dikarenakan adanya kenaikan inflasi yang cukup besar dan hal tersebut cukup berpengaruh pada program yang sedang berjalan. Beberapa program yang dijalankan di tahun 2014 yang tertuang dalam LKPJ Yogyakarta antara lain :

1. Percepatan pelaksanaan registrasi, penetapan, dan pelestarian warisan cagar budaya baik bergerak maupun tidak bergerak ;

2. Penguatan jejaring stakeholders yang meliputi pemerintah, masyarakat, perguruan tinggi, swasta, dan lembaga keuangan dalam hal peningkatan penegakan, pengawasan, dan kesadaran hukum pelestarian budaya;

3. Menggerakkan partisipasi aktif masyarakat dalam pengelolaan aset-aset budaya.

Selain itu, terjadi penurunan menjadi $44,68 \%$ karena di tahun 2015 inflasi mulai turun. Selanjutnya, pada tahun 2016, terjadi penurunan belanja langsung yang sangat drastis hingga menjadi $-55,63 \%$. Hal ini dikarenakan realisasi belanja langsung lebih kecil dari tahun sebelumnya. Realisasi anggaran belanja langsung pada periode ini cukup rendah dikarenakan adanya program yang tidak dijalankan, seperti program peningkatan kapasitas sumber daya aparatur.

Berbeda dengan pertumbuhan belanja daerah dan belanja langsung, pertumbuhan belanja tidak langsung memiliki persentase yang relatif lebih stabil. Pada tahun 2013, pertumbuhan belanja tidak langsung adalah sebesar $1,67 \%$, sedangkan pada tahun 2014, pertumbuhan belanja mulai mengalami penurunan ke nilai $0,06 \%$. Hal ini terjadi karena kenaikan harga yang tinggi, yang membuat

Tabel 4. Analisis Pertumbuhan Belanja Langsung

\begin{tabular}{cccc}
\hline Tahun & $\begin{array}{c}\text { Realisasi Anggaran } \\
\text { Belanja Langsung (Rp) }\end{array}$ & $\begin{array}{c}\text { Pertumbuhan } \\
\text { Belanja (Rp) }\end{array}$ & Keterangan (\%) \\
\hline 2012 & 38.259 .468 .193 & - & 0,00 \\
2013 & 45.315 .146 .222 & 7.055 .678 .029 & 18,44 \\
2014 & 231.734 .805 .692 & 186.419 .659 .470 & 411,38 \\
2015 & 335.272 .372 .882 & 103.537 .567 .190 & 44,68 \\
2016 & 148.769 .667 .998 & $(186.502 .704 .884)$ & $-55,63$ \\
\hline
\end{tabular}

Sumber : Dinas Kebudayaan DIY (Data Diolah)

Tabel 5. Analisis Pertumbuhan Belanja Tidak Langsung

\begin{tabular}{cccc}
\hline Tahun & $\begin{array}{c}\text { Realisasi Anggaran } \\
\text { Belanja Tidak Langsung (Rp) }\end{array}$ & $\begin{array}{c}\text { Pertumbuhan } \\
\text { Belanja (Rp) }\end{array}$ & Keterangan (\%) \\
\hline 2012 & 8.821 .256 .563 & - & $0,00 \%$ \\
2013 & 8.968 .484 .067 & 147.227 .504 & $1,67 \%$ \\
2014 & 8.974 .155 .266 & 5.671 .199 & $0,06 \%$ \\
2015 & 9.616 .774 .015 & 642.618 .749 & $6,68 \%$ \\
2016 & 10.312 .222 .935 & 695.448 .920 & $6,74 \%$ \\
\hline
\end{tabular}

Sumber : Dinas Kebudayaan DIY (Data Diolah) 
Dinas Kebudayaan DIY mengendalikan penetapan harga yang ketat pada belanja tidak langsung (tunjangan keluarga, tunjangan fungsional umum, dan tunjangan beras), sehingga efisiensi anggaran dapat dilakukan. Namun, di tahun 2015, Dinas Kebudayaan DIY mulai mengalami pertumbuhan yang cukup signifikan yaitu sebesar 6,68\% dan tahun 2016 meningkat sebesar 6,74\% dikarenakan dalam rincian LRA Dinas Kebudayaan DIY terdapat perubahan pemakaian peraturan tentang pegawai negeri yang semula PP No. 7 tahun 1997 diubah menjadi PP No. 30 tahun 2015 yang mengatur kenaikan gaji pegawai negeri. Secara keseluruhan, pertumbuhan belanja Dinas Kebudayaan DIY sudah cukup baik. Peningkatan pertumbuhan belanja terjadi karena adanya kenaikan terkait dengan penyesuaian terhadap inflasi, penyesuaian makro ekonomi, dan adanya perubahan kurs rupiah.

\section{Analisis Keserasian Belanja}

Analisis Belanja Operasi Terhadap Total Belanja. Berdasarkan analisis keserasian yang telah dilakukan terhadap data belanja operasi tahun 2012 - 2016, diperoleh hasil seperti ditunjukkan pada tabel 6. Pada tahun 2012, Dinas Kebudayaan DIY menggunakan belanja operasi sebesar 69,56\% dari total belanja dengan realisasi anggaran sebesar Rp32.749.365.281. Peningkatan terjadi di tahun 2013 hingga mecapai angka 90,92\%. Peningkatan tahun 2012 ke 2013 terjadi karena belanja barang dan jasa yang mendominasi penggunaan anggaran belanja operasi yaitu sebesar Rp 19.173.309.477. Namun, tahun 2014 dinas mulai mengurangi belanja operasi sehingga realisasinya hanya sebesar $88,13 \%$ dan 2015 turun menjadi 71,45\% dari total belanja. Tahun 2016 rasio belanja operasi di Dinas Kebudayaan DIY meningkat menjadi $86,60 \%$. Belanja operasi dengan rata rata realisasi $81,33 \%$ dapat dikatakan baik karena Dinas Kebudayaan DIY lebih mendominasi ke belanja daerah yang digunakan untuk pemeliharaaan sarana dan prasarana contohnya revitalisasi di Benteng Vredeburg dan Tugu Pal Putih hal ini dilakukan dalam upaya untuk peningkatan aktivitas dan pelayanan publik. Pada umumnya proporsi belanja operasi mendominasi belanja daerah, yaitu antara 60 - 90 persen (Mahmudi, 2007).

Analisis Belanja Modal Terhadap Total Belanja. Hasil perhitungan analisis belanja modal terhadap total belanja ditunjukkan dalam tabel 7 . Berdasarkan hasil perhitungan pada tabel 7, diketahui bahwa Dinas Kebudayaan DIY melakukan belanja modal secara rutin dari tahun 2012 - 2016. Rasio belanja modal pada tahun 2012 adalah sebesar $30,44 \%$ dari total belanja, atau sebesar $\mathrm{Rp}$ 14.331.359.475. Selanjutnya, pada tahun 2013, realisasi belanja modal Dinas Kebudayaan DIY menjadi 9,08\%. Angka tersebut turun dari tahun sebelumnya dikarenakan belanja tanah, belanja gedung, dan bangunan sudah dilakukan di tahun sebelumnya. Pada tahun tersebut, dinas hanya menggunakan belanja modal sebesar $\mathrm{Rp}$ 4.926.501.320 karena dinas mengalokasikan dana belanja ke pos-pos yang lebih penting seperti belanja operasi. Peningkatan rasio belanja modal terjadi pada tahun 2014 dan 2015 dalam penggunaan belanja modal yaitu sebesar $11,87 \%$ dan

Tabel 6. Analisis Belanja Operasi terhadap Total Belanja

\begin{tabular}{cccc}
\hline Tahun & $\begin{array}{c}\text { Realisasi } \\
\text { Belanja Operasi (Rp) }\end{array}$ & $\begin{array}{c}\text { Total } \\
\text { Belanja Daerah (Rp) }\end{array}$ & $\begin{array}{c}\text { Rasio Belanja Operasi } \\
\text { terhadap Total Belanja (\%) }\end{array}$ \\
\hline 2012 & 32.749 .365 .281 & 47.080 .724 .756 & $69,56 \%$ \\
2013 & 49.357 .128 .969 & 54.283 .630 .289 & $90,92 \%$ \\
2014 & 212.148 .814 .688 & 240.708 .960 .958 & $88,13 \%$ \\
2015 & 246.413 .983 .696 & 344.889 .146 .897 & $71,45 \%$ \\
2016 & 137.761 .168 .528 & 159.081 .890 .933 & $86,60 \%$ \\
\hline
\end{tabular}

Sumber : Dinas Kebudayaan DIY (Data Diolah)

Tabel 7. Analisis Belanja Modal terhadap Total Belanja

\begin{tabular}{cccc}
\hline Tahun & $\begin{array}{c}\text { Realisasi } \\
\text { Belanja Modal (Rp) }\end{array}$ & $\begin{array}{c}\text { Total } \\
\text { Belanja Daerah (Rp) }\end{array}$ & $\begin{array}{c}\text { Rasio Belanja Modal } \\
\text { terhadap Total Belanja (Rp) }\end{array}$ \\
\hline 2012 & 14.331 .359 .475 & 47.080 .724 .756 & $30,44 \%$ \\
2013 & 4.926 .501 .320 & 54.283 .630 .289 & $9,08 \%$ \\
2014 & 28.560 .146 .270 & 240.708 .960 .958 & $11,87 \%$ \\
2015 & 98.475 .163 .201 & 344.889 .146 .897 & $28,55 \%$ \\
2016 & 21.320 .722 .405 & 159.081 .890 .933 & $13,40 \%$ \\
\hline
\end{tabular}

Sumber : Dinas Kebudayaan DIY (Data Diolah) 
tahun 2015 sebesar 28,55\% dari total belanja. Berdasarkan rincian LRA tahun 2015 peningkatan dikarenakan adanya pengadaan belanja modal berupa kendaraan dinas baru, belanja modal tanah, dan peralatan mesin yang tinggi dari tahun sebelumnya, sementara ditahun 2015 Dinas Kebudayaan DIY tidak menggunakan anggaran untuk belanja jalan, irigasi, dan jaringan dan belanja aset lainnya. Sementara itu, untuk tahun 2016, realisasi belanja modal turun menjadi 13,40\% dikarenakan Dinas tidak menggunakan belanja modal tanah dan dialokasikan ke pos pos yang lain. Setiap tahunnya, peningkatan terjadi pada realisasi belanja daerah. Namun, rasio belanja modal masih berfluktuasi, hal ini disebabkan karena dinas lebih berorientasi pada belanja operasi.

Analisis Belanja Langsung dan Tidak Langsung. Berdasarkan hasil analisis belanja langsung dan tidak langsung Dinas Kebudayaan DIY tahun 2012 2016, diketahui bahwa secara keseluruhan rasio belanja langsung lebih besar dari belanja tidak langsung terhadap total belanja. Pada tahun 2012, anggaran belanja langsung terealisasi sebesar $81,26 \%$ sedangkan untuk belanja tidak langsung hanya terealisasi sebesar $18,47 \%$. Realisasi belanja langsung terus meningkat setiap tahunnya. Dapat dilihat bahwa pada tahun 2013, rasionya adalah sebesar $83,48 \%$ dan terus meningkat pada tahun 2014 dan 2015.

Penurunan tidak signifikan terjadi di tahun 2016, yaitu ke angka 93,52\%. Hal ini tidak berpengaruh buruk karena di tahun 2016 program yang dilaksanakan adalah lanjutan dari program tahuntahun sebelumnya dan program baru. Seperti yang tertera dalam LKPJ Yogyakarta program yang dilaksanakan tahun tersebut antara lain:

1. Menghadirkan Tata Nilai Jogjakarta dalam ruang publik melalui media sosial, media cetak, media elektronik, dan media luar ruang melalui wujud yang populer dan menarik.

2. Pemajuan manajemen penyelenggaraan Upacara Adat dan Upacara Tradisi

3. Peningkatan kualitas SDM dan Pengembangan asosiasi organisasi seni dan film

4. Pengelolaan Kawasan Cagar Budaya

5. Peningkatan peran Pengelola Desa/Kelurahan budaya dan masyarakat

6. Penataan fisik museum diikuti dengan penyelenggaraan event edukasi

Berbeda dengan belanja langsung yang cenderung meningkat, rasio belanja tidak langsung cenderung turun dan berfluktuasi. Pada tahun 2012, realisasi anggaran belanja tidak langsung adalah sebesar 18,74\%. Realisasi anggaran belanja tidak langsung tahun 2012 ini memiliki persentase paling tinggi. Pada tahun 2013, anggaran belanja tidak langsung mulai menurun ke angka 16,52\% dan menurun lagi pada tahun 2014 yang hanya sebesar $3,73 \%$. Sementara itu, pada tahun 2015, realisasinya mencapai 2,79\% dari total belanja. Dinas berupaya menekan pengeluaran belanja tidak langsung dengan mengurangi tunjangan di tahun 2014. Tunjangan yang dikurangi adalah tunjangan keluarga, tunjangan fungsional, dan tunjangan beras, sedangkan di tahun 2015 dinas memilih untuk mengurangi pembulatan gaji sebesar Rp 104.467.

Tabel 8. Analisis Belanja Langsung terhadap Total Belanja

\begin{tabular}{cccc}
\hline Tahun & $\begin{array}{c}\text { Realisasi } \\
\text { Belanja Langsung (Rp) }\end{array}$ & $\begin{array}{c}\text { Total } \\
\text { Belanja Daerah (Rp) }\end{array}$ & $\begin{array}{c}\text { Rasio Belanja Langsung } \\
\text { terhadap Total Belanja }(\%)\end{array}$ \\
\hline 2012 & 38.259 .468 .193 & 47.080 .724 .756 & 81,26 \\
2013 & 45.315 .146 .222 & 54.283 .630 .289 & 83,48 \\
2014 & 231.734 .805 .692 & 240.708 .960 .958 & 96,27 \\
2015 & 335.272 .372 .882 & 344.889 .146 .897 & 97,21 \\
2016 & 148.769 .667 .998 & 159.081 .890 .933 & 93,52 \\
\hline
\end{tabular}

Sumber : Dinas Kebudayaan DIY (Data Diolah)

Tabel 9. Analisis Belanja Tidak Langsung terhadap Total Belanja

\begin{tabular}{cccc}
\hline Tahun & $\begin{array}{c}\text { Realisasi Belanja } \\
\text { Tidak Langsung (Rp) }\end{array}$ & $\begin{array}{c}\text { Total } \\
\text { Belanja Daerah (Rp) }\end{array}$ & $\begin{array}{c}\text { Rasio Belanja Tidak Langsung } \\
\text { terhadap Total Belanja (\%) }\end{array}$ \\
\hline 2012 & 8.821 .256 .563 & 47.080 .724 .756 & 18,74 \\
2013 & 8.968 .484 .067 & 54.283 .630 .289 & 16,52 \\
2014 & 8.974 .155 .266 & 240.708 .960 .958 & 3,73 \\
2015 & 9.616 .774 .015 & 344.889 .146 .897 & 2,79 \\
2016 & 10.312 .222 .935 & 159.081 .890 .933 & 6,48 \\
\hline
\end{tabular}

Sumber : Dinas Kebudayaan DIY (Data Diolah) 


\section{Rasio Efisiensi Belanja}

Dinas Kebudayaan DIY menggunakan anggaran belanja di tahun 2012 sebesar 94,30\%. Besarnya persentase ini dikarenakan dinas mempunyai program yang harus di selesaikan pada tahun tersebut, salah satunya pengupayaan pembebasan lahan tenggara Tugu yang menggunakan dana sebesar Rp 1.491.370.000. Sementara itu, untuk tahun 2013 persentase menurun menjadi sebesar $32,38 \%$. Pada tahun tersebut, terjadi efisiensi anggaran yang cukup besar, dikarenakan adanya program pembinaan organisasi budaya yang belum rampung, keterbatasan waktu dan pembinaan sehingga dilanjutkan ditahun berikutnya. Peningkatan penggunaan anggaran kembali terjadi di tahun 2014 menjadi 58,93\% dari total anggaran. Peningkatan terus dilakukan, ditandai adanya peningkatan pemakaian anggaran belanja di tahun 2015 yaitu sebesar 83,97\% dan di tahun 2016 sebesar 93,68\%. Efisiensi anggaran belanja di Dinas Kebudayaan DIY cukup baik karena semua perhitungan persentase rasio efisiensi tidak lebih dari $100 \%$. Tabel $10 \mathrm{di}$ bawah ini menunjukkan rasio efisiensi belanja Dinas Kebudayaan DIY.
Selain mengadakan program kebudayaan, Dinas Kebudayaan DIY juga mengadakan program non kebudayaan yang bertujuan untuk meningkatkan kecakapan sumber daya manusia (SDM) maupun peningkatan sarana prasarana penunjang di Dinas Kebudayaan DIY. Program kerja yang dilaksanakan setiap tahun di Dinas Kebudayaan DIY disajikan pada Tabel 11.

Berdasarkan hasil perhitungan tabel 11, diketahui bahwa Dinas Kebudayaan DIY melakukan efisiensi belanja program setiap tahunnya. Tahun 2015 adanya program peningkatan kapasitas sumberdaya aparatur yang rendah sesuai dengan penjabaran LRA Dinas Kebudayaan DIY, Dinas tidak boleh mengadakan seminar kit sesuai arahan dari Tim Anggaran Pemerintah Daerah (TAPD). Efisiensi Program yang baik terlihat dari tahun 2012 hingga 2016. Namun, tahun 2012 ada salah satu program yang tidak efisien yaitu program peningkatan kapasitas sumber daya aparatur karena pemakaian anggaran yang mencapai 100\%. Meskipun demikian, dinas berusaha melakukan efisiensi dari tahun 2013 hingga 2016. Terjadi penurunan yang sangat drastis di tahun 2016 yaitu dari 82,64\% ke 62,05\%. Hal ini disebabkan karena ada program yang tidak terlaksana oleh dinas terkait.

Tabel 10. Rasio Efisiensi Belanja

\begin{tabular}{cccc}
\hline Tahun & Realisasi Belanja (Rp) & Anggaran Belanja (Rp) & Rasio Efisiensi Belanja (\%) \\
\hline 2012 & 47.080 .724 .756 & 49.927 .729 .881 & 94,30 \\
2013 & 54.283 .630 .289 & 167.644 .664 .546 & 32,38 \\
2014 & 240.708 .960 .958 & 408.481 .993 .909 & 58,93 \\
2015 & 344.889 .146 .897 & 410.750 .387 .594 & 83,97 \\
2016 & 159.081 .890 .933 & 169.816 .967 .276 & 93,68 \\
\hline
\end{tabular}

Sumber:Dinas Kebudayaan DIY Data Diolah)

Tabel 11. Rasio Efisiensi Belanja Program Dinas Kebudayaan DIY

\begin{tabular}{llllll}
\hline Uraian Program & \multicolumn{5}{c}{ Efisiensi Belanja Program (\%) } \\
\cline { 2 - 6 } Program Pelayanan Administrasi Perkantoran & 2012 & 2013 & 2014 & 2015 & 2016 \\
\cline { 2 - 6 } Program Peningkatan Sarana dan Prasarana Aparatur & 91,18 & 90,37 & 80,61 & 95,30 & 93,08 \\
Program Peningkatan Kapasitas Sumberdaya Aparatur & 93,45 & 91,34 & 81,12 & 83,29 & 85,68 \\
$\begin{array}{l}\text { Program Peningkatan Pengembangan Sistem Pelaporan } \\
\text { Capaian Kerja dan Keuangan }\end{array}$ & 100,00 & 99,79 & 97,22 & 85,32 & - \\
Rata-rata & 93,75 & 89,62 & 93,22 & 66,67 & 69,44 \\
\hline
\end{tabular}

Sumber : Dinas Kebudayaan DIY (Data Diolah)

Tabel 12. Rasio Efektivitas Belanja Tidak Langsung

\begin{tabular}{cccc}
\hline Tahun & $\begin{array}{c}\text { Realisasi Belanja } \\
\text { Tidak Langsung (Rp) }\end{array}$ & $\begin{array}{c}\text { Target Belanja } \\
\text { Tidak Langsung (Rp) }\end{array}$ & $\begin{array}{c}\text { Rasio } \\
\text { Efektivitas Belanja (\%) }\end{array}$ \\
\hline 2012 & 8.821 .256 .563 & 8.996 .929 .806 & $98,05 \%$ \\
2013 & 8.968 .484 .067 & 9.042 .677 .321 & $99,18 \%$ \\
2014 & 8.974 .155 .266 & 8.999 .795 .609 & $99,72 \%$ \\
2015 & 9.616 .774 .015 & 9.749 .986 .869 & $98,63 \%$ \\
2016 & 10.312 .222 .935 & 10.860 .592 .139 & $94,95 \%$ \\
Rata-rata & & & $98,11 \%$ \\
\hline
\end{tabular}

Sumber : Dinas Kebudayaan DIY (Data Diolah) 


\section{Rasio Efektivitas}

Untuk melakukan analisis ini, diperlukan data anggaran belanja tidak langsung tahun 2012-2016. Berdasarkan hasil perhitungan Tabel 12, diketahui bahwa tingkat efektivitas pengelolaan belanja tidak langsung Dinas Kebudayaan DIY tahun 2012 hingga 2016 memiliki rata-rata 98,11\%. Hal ini mengindikasikan adanya efektivitas yang dilakukan dinas, karena hasil perhitungan yang menunjukkan angka lebih dari 90\%. Hasil efektivitas paling baik terjadi di tahun 2014 dengan besaran efektivitas mencapai 99,72\%. Hal ini terjadi karena di tahun tersebut dinas meningkatkan belanja gaji PNS/uang representasi, tunjangan jabatan, dan tunjangan Pajak Penghasilan (PPH)/ tunjangan khusus. Sementara itu, efektivitas paling rendah terjadi di tahun 2016 dengan persentase sebesar 94,95\%. Namun, realisasi dan targetnya paling tinggi. Hal ini disebabkan karena adanya perekrutan pegawai baru di Dinas Kebudayaan DIY di akhir tahun dan perubahan penggunaan PP No. 7 tahun 1977 menjadi PP No. 30 tahun 2015 tentang peraturan pegawai negeri yang berimbas pada pemakaian anggaran dan realisasinya.

\section{SIMPULAN}

Hasil analisis varians belanja Dinas Kebudayaan DIY tahun 2012 - 2016 menunjukan kinerja yang baik, sesuai dengan Mahmudi (2007) yang menyatakan bahwa kinerja anggaran dikatakan baik jika penggunaan realisasi anggaran lebih rendah daripada jumlah yang dianggarkan. Sementara itu, pertumbuhan belanja Dinas Kebudayaan DIY tahun 2012 - 2016 dapat dikatakan cukup fluktuatif di antranya disebabkan oleh faktor inflasi dan adanya program yang tidak terselenggara pada tahun 2016. Hasil analisis keserasian belanja menunjukkan bahwa Dinas Kebudayaan DIY sudah melakukan harmonisasi belanja. Hal ini dibuktikan dengan proporsi belanja operasi yang lebih besar dari belanja modal, dan belanja langsung yang proporsinya lebih besar dari belanja tidak langsung.

Ditinjau dari segi efisiensi belanja, Dinas Kebudayaan DIY sudah melakukan efisiensi dengan baik. Hal tersebut dibuktikan dengan tingkat rasio efisiensi yang kurang dari 100\%. Namun, untuk efisiensi program ada salah satu program yang tidak berjalan secara efisien di Dinas Kebudayaan DIY. Berdasarkan hasil perhitungan dari rasio efektivitas belanja tidak langsung, Dinas Kebudayaan DIY menunjukkan bahwa belanja tidak langsung sudah berjalan secara efektif. Hal tersebut dibuktikan dengan tingkat rasio efektivitas yang yang menunjukkan angka lebih dari 90\%. Secara umum, dapat disimpulkan bahwa kinerja anggaran belanja Dinas Kebudayaan DIY tahun 2012-2016 sudah baik.

Karena penelitian ini memiliki keterbatasan dalam literatur terkait potensi budaya Yogyakarta yang ditinjau dari berbagai macam perspektif, misalnya perspektif wisatawan akan wisata budaya di Yogyakarta dan perspektif keyakinan pemerintah daerah Yogyakarta akan potensi budaya setempat. Selain itu, izin akses data yang terbatas menyebabkan kurang luasnya rentang waktu yang Dianalisis. Berdasarkan hasil analisis dan kesimpulan yang telah diuraikan, maka disarankan kepada peneliti selanjutnya untuk mengembangkan ide-ide yang lebih luas dan mendalam, misalnya dengan menganalisis kinerja anggaran dari sisi pendapatan pada daerah-daerah dengan potensi pendapatan yang besar ataupun kecil, pada periode yang lebih mutakhir. Selain itu, perlu ditinjau lebih lanjut relevansi alat ukur yang digunakan pada penelitian ini untuk digunakan di berbagai daerah dengan karakteristik yang berbeda.

\section{DAFTAR PUSTAKA}

Adrisijanti, I. (2007). "Kota Yogyakarta Sebagai Kawasan Pusaka Budaya Potensi dan Permasalahannya”. Disajikan dalam Diskusi Sejarah "Kota dan Perubahan Sosial dalam Perspektif Sejarah”, diselenggarakan oleh Balai Pelestarian Sejarah dan Nilai Tradisional Yogyakarta, 11-12 April 2007.

Badan Pusat Statistik, tentang data inflasi di Indonesia, diakses 6 Juni 2017, https://www.bps.go.id/linkTabelStatis/view/id 1907.

Bastian, I. (2006). Sistem Perencanaan dan Penganggaran Pemerintahan Daerah di Indonesia. Yogyakarta: Salemba Empat.

Darise, N. (2007). Pengelolaan Keuangan pada Satuan Kerja Perangkat Daerah (SKPD). Gorontalo: Indeks.

Fahrianta, R. Y. \& Carolina, V. (2012). Analisis Efisiensi Anggaran Belanja Dinas Pendidikan Kabupaten Kapuas. Jurnal Manajemen Akuntansi, 13(1), 57-72.

Halim, A. \& Kusufi, M. S. (2014). Teori, Konsep, dan Aplikasi Akuntansi Sektor Publik. Yogyakarta: Salemba Empat.

Kainde, C. (2013). Analisis Varians dan Pertumbuhan Belanja Daerah pada Pemerintah Kota Bitung. Jurnal EMBA, 1(3), 393-400.

Laporan Keterangan Pertanggungjawaban 2012-2016. (2016). Yogyakarta.

Liando, G. Y. \& Elim, I. (2016). Analisis Kinerja Belanja dalam Laporan Realisasi Anggaran (LRA) pada Dinas Pendapatan Pengelolaan 
Keuangan dan Aset Daerah Kabupaten Kepulauan Sangihe. Jurnal EMBA, 4(1), 1473 1484.

Mahmudi. (2007). Analisis Laporan Keuangan Pemerintah Daerah. Yogyakarta: UPP STIM YKPN.

Mahsun, M. (2016). Pengukuran Kinerja Sektor Publik. Yogyakarta: BPFE.

Mardiasmo. (2007). Akuntansi Sektor Publik. Yogyakarta: Andi Offset.

Pangkey, I. \& Pinatik, S. (2015). Analisis Efektivitas dan Efisiensi Anggaran Belanja pada Dinas Kebudayaan dan Pariwisata Provinsi Sulawesi Utara. Jurnal EMBA, 3(4), 33-43.

Sasana, H. (2011). Analisis Determinan Belanja Daerah di Kabupaten/Kota Provinsi Jawa Barat dalam Era Otonomi dan Desentralisasi Fiskal. Jurnal Bisnis dan Ekonomi (JBE), 18(1), 46-58.

Yunus, R. (2013). Transformasi Nilai-Nilai Budaya Lokal Sebagai Upaya Pembangunan Karakter Bangsa. Jurnal Penelitian Pendidikan, 13(1),15-21. 